\title{
The Phenomenon of Resilience in the Biography Narratives of the Gdańsk Seniors
}

\begin{abstract}
The narratives included in this article were collected within the framework of the project "We Support Senior Citizens in the Local Environment - Culture as an Element of the Identity of the Elderly", implemented in the Daily Care Home of the Local Support Center in Gdańsk in 2016. They are the result of the author's personal observations of seniors being in need of telling their past, sharing it, and at the same time sorting it out, and reconciling themselves with the difficult moments in their lives. There is also a need for reflection on one's past, which gives power and strength to go on in life. In other words, who and/or what makes you want to live and even enjoy life? What is resilience in my life? Remaining impressed by the power of their stories, the stories of people who in the moments of difficulty and pain were able to say: 'I want to live', and asking them to reflect on the past, I came to realize what it is that determines the sources to keep the resilience described below and the ability to regenerate.
\end{abstract}

Keywords:

resilience, biography narrative, senior, individual conditioning, social and culture conditioning

\section{THEORETICAL AND METHODOLOGICAL BASIS}

The concept of resilience explains the phenomenon of positive adaptation of people exposed to various types of adversities or traumatic events (Borucka \& Pisarska, 2012). It means a relatively good adaptation of the person despite the experienced threat (Olsson, Bond, Burns, Vella-Brodrick, \& Sawyer, 2003). The perception of 
resilience as a way to overcome negative phenomena in life is, in turn, proposed by Ogińska-Bulik and Jurczyński (2011).

The English term 'resilience' is also used in the Polish version of the article as it seems to be the most appropriate to render the discussed concept. The related notions are flexibility, ability to regenerate (Borucka \& Ostaszewski, 2008). This term was introduced to social sciences by the pioneers of research into the development of disadvantaged children and adolescents, Norman Garmezy and Michael Rutter (Rutter, 1987). Resilience means, in this usage, smooth functioning in difficult life periods, having age-appropriate skills and carrying on with life in spite of adversity. In a wider sense, resilience is a dynamic process of adaptation despite experienced hazards or traumas. Another meaning of the term can be "rebounding from the bottom", that is resuming normal functioning after a "very stressful event” (Borucka \& Ostaszewski, 2008, pp. 2-4). Essentially, resilience is not the same as good mental health or good social competence, it is rather an ability of the individual to maintain composure in the face of adversity.

Unfavourable conditions of development, understood as risk factors, can cause deviations in the psyche. The risk factors include: prematurity, poverty, mental illness of the parents, war, divorce, childcare by the institutions (Borucka \& Ostaszewski, 2008). However, the presence of one risk factor is not sufficient to cause malfunction in the person. There are four risk-metrics: individual characteristics (self-esteem, cheerful disposition, religious beliefs, talent, sociability), peer influence, family relationships (family cohesion, close relationships, warmth, good financial situation), place of residence and social relations (Borucka \& Ostaszewski, 2008). In turn, the areas of protective factors that have the power to counteract the effects of risk factors include: individual characteristics, family factors and external factors such as the safe neighborhood, membership of a prosocial organization (Borucka \& Ostaszewski, 2008).

This topic needs qualitative research, where the man is in the center of the research. In my opinion, getting to know the man needs qualitative approach. I reach for conception of grounded theory by Glaser and Strauss (cf. Charmaz, 2009, pp. 10-17). This theory assumes that people create their world because they have patterns of experiences which transfer their interactions. Quantitative research does not give a full picture of all respondents. The general purpose of biographical research is provided by meaning of individual life.

The method I used is autobiographical interview that embraces life-story - it is a life-course containing childhood and its influence on respondents' present life. Qualitative research allows to have interactions with people and get to know their life-stories. Grounded theory is a field which emphasizes the essence of the idea 
of interactions in the world. All respondents were the participants in the project which I wrote for inmates in the Daily Care Home of the Local Support Center in Gdańsk in 2016.

\section{BIOGRAPHICAL METHOD}

The narrative 'has a healing power', says Grażyna Jagielska (2014, p. 82), describing her stay in the Department of Psychiatry and Combat Stress in Warsaw, where, as a wife of a war correspondent, constantly exposed to death, she tells her own story, thus creating a chance to "be on the side of life" (Jagielska, 2014, p. 100).

This power has been confirmed by numerous researchers dealing with narrative biography (Skibińska, 2006). Maria Mendel writes: “The biographical method makes it possible to analyze specific problems in the context of vital life narratives and to give an opportunity to refer to the time and places where they occurred" (Mendel, 2007, p. 90). The therapeutic function accompanying the narrative of one's own life story allows the person to look at their own life from a completely different perspective and make changes in it. Anthony Giddens observes: "Autobiography is not a mere chronicle of past events but a corrective intervention in the past. One example of such an interference of the individual in his or her past is taking care of oneself as a child” (Giddens, 2002, p. 101). Finding your inner child who is waiting for support takes on therapeutic dimensions, gives you a feeling of strength and energy - "Everyone who talks about their life holds it in their hands," as Duccio Demetrio points out (2000, p. 9).

The scientific backdrop of the biographical method can be found in narrative psychology and in philosophical anthropology at the turn of the nineteenth century (Straś-Romanowska, 2005). P. Dominicè, reflecting on the causes leading to the use of the biographical method, points towards the aging of the population and a new way of looking on the life process, as well as economic crises and unemployment, which often lead to a new look at one's own biography (Dominicè, 2006). As a researcher, I am primarily interested in the subjective viewpoints of the narratives studied and the social and cultural context of the phenomenon of resilience that I study.

\section{ANALYTICAL ATTEMPTS}

In the narrative stories of the six seniors taking part in the project I find a number of elements related to the question of resilience. They are marked by the capital letter [S] and the respective number. The participants are five women and one man. 


\section{INDIVIDUAL CHARACTERISTIC, SOCIAL AND CULTURAL CONTEXTS}

Most of the interviews start with the individual characteristic of the seniors including their origin and their family background. One participant introduces social context of her life: "When the war broke out I was fourteen [...] my parents were worried about me" [S2]. In her memoirs one can find elements related to religious beliefs and rituals: "I remember how the pilgrimage that was going from Wejherowo to Jasna Góra stopped in Rumia because of the outbreak of the Second World War. [...] I remember the First Holy Communion, when Piłsudski died and we were in church for a Mass for him” [S2].

Further in her story, she shows her ability to pursue her own plans, "I wanted to live in town. [...]. I was able to cope, I completed a course for waiters and worked [...] as a waitress, a barmaid" [S2]. At the same time she mentions her passions: "I loved theater and operettas. We often went to the theater to the Forest Opera in Sopot" [S2].

Another of the seniors begins her story: "I was born in a village in Masovia [...] I had the feeling that I was happy, I didn’t talk about it, but I just had that feeling. When I looked at nature, the fields, I was happy, and when I come back to these memories, I feel happiness" [S3]. Her optimism and cheerful attitude to her past stand out against the background of other narratives. Then her determination and commitment to the tasks she had undertaken: "I used to be so absorbed in a mathematical problem until I solved it. The whole class would wait for me to do it. And as a rule, I always managed to" [S3].

Next senior also talks about herself by beginning with the place where she lived and was born: "I came to Gdańsk in 1975 with my husband because he had been granted a flat by his company, the Gdańsk Refinery. Our daughter was then two months old" [S4]. She sees herself as one on the side of those fighting for a better world: "[...] because I am the kind of person who wants to repair the world, I want to fight for justice, people being rude irritate me. But you cannot do it alone, you must have some back up" [S4].

When it comes to the male participant, in his biographical narrative he mentions the place of birth and the professional role of his parents: "I was born in Kraków in 1932 into a military family, my father was an officer of the Polish Army. My mom was a teacher” [S5]. His social background and education led him towards educational studies, despite the wartime, beginning with three grades of the underground school, and then "The Third Junior Grammar School named after King John III Sobieski. After leaving junior grammar school I went to chemistry grammar school. I started my studies at the Evening School of Engineering in Kraków. [...] In 1956, I graduated from the Silesian University of Technology. I received a work order and with a chemistry engineer diploma I started working 
in the Silesian Refinery in Gliwice” [S5]. The educational theme related to social origins and the ethos of education is strongly emphasized here.

Finally, the last participant begins with identifying her birthplace, but, surprisingly, she immediately degrades it, confessing: “I was born in Poznań, I did not like Poznań [...]. I always liked the Baltic Coast. In 1953, I got married and came to Gdańsk. I was very happy then” [S6].

\section{FAMILY RELATIONS}

For one of the seniors, childhood in the family home was a particularly difficult time, as she recalls, "My home was bad. Daddy beat me, he abused alcohol. When my mother defended me, my father was upset, kicking up a fuss. I was fourteen when my dad raped me [...]. I was in hospital [...]. Then my dad was locked up in prison for eight years” [S1]. Her childhood marked by harm and lack of effective defense caused a number of circumstances unfavourable to her development: "I started running away from home. I wanted to live alone and not be locked up in psychiatric hospitals [...]. My mother was with me for medical visits and because of epileptic attacks I was referred for closed therapy" [S1].

The problems of family relationships were strongly connected with health problems, which in turn influenced the form of social relationships, so important for a growing person, as it is pointed out in the theory of psychosocial development of man (Erikson, 2002). Later in her adulthood the consequences turned out to be enormous, as the woman tells her story: her husband's unfaithfulness, eviction from the apartment, alcohol abuse, and consequently: "I ran away from home with my daughter and son [...]. When I came to Gdańsk, they took my daughter away from me. And when my son was born, they also took him away straight from the hospital because I did not have the apartment and the means to live [...]. I was deprived of parental rights, the children went together for adoption. [...] I had no choice. I did not have any means, and my husband died of alcohol abuse” [S1].

She continues that she failed to maintain a relationship with her children: "I have a grudge, I would like to have contact, but they did not want to agree to it at the Adoption Center. I do not know what they are doing now. I saw them only once, many years ago. [...]. They also did not seek contact with me. I reconciled myself to this" [S1].

There are to be found a number of risk factors related to the sphere of family and social ties. In the story of another senior, an important risk factor was the early loss of her mother and the war: "Before the liberation, in 1944 my mother died. I was the oldest and had to take care of the younger siblings and run the house" [S2]. This situation probably caused her to rapidly mature. "During the war, I was 
working on a German farm, so I was not deported. It was hard work” [S2]. When she was growing up, she said, "I had a severe stomach disease. [...]. You can live with it. I do not complain, nothing can be done. I had to come to terms with the disease" [S2]. The relationships to people and to the outside world are important to her, about her husband she says: "He was calm, he was very quiet, he had a lot of friends "[S2]. She is happy not having had to work outside home: "I did not have a job, I ran the house and raised children” [S2].

Her story comprises other extremely difficult situation: "I lost my daughter, she died in 1963 of cancer. [...] She suffered from fits caused by a tumor in the brain. She died quickly" [S2]. This situation did not cause her to remain in pain though. Close and strong family relationships seem to be a guarantee of her sense of peace and closeness: "I have a wonderful family, they care about me, sometimes I do not want to say that I feel worse not to bother them, but they watch over me. And I feel it. I'm taken care of" [S2].

This ninety-one-year-old woman looking at her life draws my attention to the last stage of human life, called by Erikson 'the integrity of the ego', understood as a tendency toward order and sense (Erikson, 2002). It results from the acceptance of one's own life. Absence or a loss of the ego integrity means fear of death, a lack of reconciliation with the passage of time and one's own past life, it means bitterness, sadness, and often despair, due to the awareness of less and less time remaining to start a new life and try new ways to integrate. According to Erikson (2002), the basic virtue of this stage of life is wisdom. In the woman's story [S2], her family ties and personal events make it possible for her to survive the painful moments of life such as the early loss of mother, the syndrome of war, the death of her beloved daughter and, at the same time, help her realize herself as a woman, wife, mother, and a person who can also take care of one's own needs.

According to Erikson, man develops throughout his life, which is accompanied by developmental changes. At maturity, an intermediate stage between childhood and adulthood, it is faithfulness that becomes the vital force, which the researcher understands as the ability of a person to trust themselves (Erikson, 2002). The lack of trust results primarily in the lack of faith in one's own strength. Erikson's faithfulness is in some sense a bridge between "childlike trust and adult faith" (Erikson, 2002). Its opposite is the rejection of the role, lack of identification with specific ways of functioning, principles, and values. In addition, adulthood has the power to become an authority, a role model (Erikson, 2002). And listening to the senior's stories about her loved ones, about those remembering her, it is hard not to guess how important she is to them: “[...] they always come to me, they have to come and I am very happy with it” [S2]. The crowning of mature life is the 
integrity of the individual in the final stage of life, a sense of the fullness of life, joy of the transition, wisdom, fulfilment, the desire to be needed (Erikson, 1997).

Another respondent's account is a sentimental view of childhood, which is reminiscent of Proust's remembrance of the past when she says, "It is hard to say that it was a happy childhood, it was simply successful. But I remember the moments when I went to school and came back, in a festive school dress that was taken off at home so as not to be stained and not to be soiled, I remember this huge satisfaction" [S3], and further, "I had two brothers, we went a lot on horseback, we swam in a pond that was very large. The women from the farm quarters came to our farm to do laundry [...]" [S3]. The figure of her father appears in her story, his important role: "I remember when he was riding a sleigh in the snow, there were beautiful sleigh rides when the snow appeared. No one else in the village did it for their children. And my dad took us in this sleigh across the fields...” [S3]. And perhaps it is not too far-fetched a conclusion to find in this account a successful marriage relation: "He was a husband [...]. Wise and good, honest, from a good family. We used to be together, spending time, traveling. I had a son and then I was still in love with him. It was a good relationship" [S3].

Another senior's account is that of difficulty experienced in her family: "It was not a good time when my son was born [...]. Mom was very sick. [...] She died of cancer, at fifty-one years only" [S4]. The woman recalls, "I had a very loving mom. I have an older brother and a younger sister" [S4]. In contrast, the relationship with her father was different: "Dad often escaped from duty. I had the best contact with my mother. Dad was seventeen when he was deported to Siberia and then he was suffering from huge health problems. He did not have good contact with us, he often went away going fishing so as to struggle with his thoughts and to stay alone” [S4], and further: "I did not have good contact with my father, he was taciturn, talked little" [S4]. A painful experience also touched her in adulthood: "When I was thirty-six, my husband left me for a younger woman, not much older than my daughter" [S4], and she adds, "We did not make a match with my husband at all." Then came another crisis: "My ex-husband kept our daughter away from me. [...].” The loss of her daughter turned out to be an experience lasting for years: "It took more than two years before the situation was resolved. And it was a blow to the heart! I saw my daughter only after a few years" [S4]. Consequently: "I suffered the first nervous breakdown. A neighbor [...] made me injections of magnesium, that helped a lot" [S4]. She explains the difficult lives of women in her family: "We were all unhappy women - my mom, me, my daughter. It is in us, it is inherited from generation to generation" [S4].

The story of the man begins quite differently: "The conditions for education I had was a greenhouse. I had an older sister and older brother [...]. Our father, as 
a soldier, kept discipline at home” [S5]. This did not last too long, because the family was broken down by war: "Our father was mobilized separately, but I was with my mother, sister and brother travelling in a freight train car" [S5], and further: "My dad was imprisoned by the Germans in the Montelupich Street prison during the war. A German doctor claimed my father had suffered an eighty-five percent health loss and so had to turn up for check-ups every week to show he was still alive" [S5]. But at the same time, in spite of all this difficult situation, he had a sense of security knowing my mother [...], he took great care [...] to provide us with food, accommodation" [S5]. During the war, she became ill with atherosclerosis and died in 1942: "I lost my mother, but my mother's loss was made up for by the care of my grandparents, who I stayed with during the occupation” [S5]. Then he got married, "A perfect wife. My first love. After the wedding we went to Nowy Sącz, to live in a house inherited after my grandparents [...]. We had somewhere to live, then there were huge housing problems" [S5]. Therefore, the factors of family ties and living conditions come into play in this case.

The last of the seniors also refers to strong relationships in the family: "I had very good parents” [S6]. When talking about herself, she speaks of her family during the wartime: "During the German occupation, there was no daddy, he was in Germany doing forced labour. He returned after the war" [S6]. Her memories of her wartime home are warm and seemed to have been transferred onto the family she started, when she ran the house and found her living condition exceptionally favourable: "We got a two-room apartment provided by the Shipyard. My husband was an engineer. I did not have a job. [... I focused on running the house and raising the children. There was no need for me to go out to work, besides, my husband would not let me do it. It was convenient for me and it was a good time for the family" [S6], she recalls with a smile.

\section{PEER INFLUENCE}

The impact of the peer community had been particularly negative in the story of the first senior: "I have bad memories of the time I was undergoing treatment, I also went to school there, but I had friends who beat me. After some beating I started to stutter" [S1]. With respect to adolescence (Erikson, 2002), the effects of childhood on the personal development are evident: "When I ran away, I spent nights at my friends' places, went to school, or played truant. I learned to smoke and went to school less and less. I sometimes slept in the forest” [S1]. What followed is equally difficult: "When I was eighteen, I came to Gdańsk, but I did not have any ID, only the one I had got from a friend. The police stopped me, my friend told them I had stolen it from her. I spent three years in jail, it was the martial law time of 1981-83” [S1]. 
Erikson writes about the period of adolescence, describing it as identity/dispersion of identity, when peer relationships and external leadership patterns become significant. Then it is the time for the adolescence period, the physiological evolution and the first "adult" tasks should begin. Integration is perceived here as a process of forming the identity of the ego. The identity of the ego is the result of the person's self-confidence, continuity and internal identity that had arisen earlier (Erikson, 2002). Erikson calls the period of adolescence moratorium, a psychosocial phase between childhood and adulthood, between the morality of the child and the ethics of an adult (Erikson, 1997, p. 274). The vital force is faithfulness, which is understood as the ability to trust oneself in the period of self-determination and search for social values and ideals. On the other hand, lack of trust results primarily in a lack of faith in one's own strengths and in the rejection of the role, and a lack of identification with specific ways of functioning (Erikson, 2002).

The woman marked as [S1] seems to be an exemplification of this condition, where there is rejection of the role and a sense of total loneliness and helplessness leading to escapist reactions and joining risk groups. This identity disorder does not allow for a genuine engagement, so she remains in a rigid reserve and is unable to establish intimacy (Erikson, 1972). She often enters into stiff, shady relationships (peers, husband), or with random strangers, where she does not know how to fulfil herself (Erikson, 1972).

Another woman's story presents a completely different scenario of maturity process, that of family love and acceptance: "I had the feeling that I was happy, no one talked about it, but I just had that feeling" [S3], and then she remembers her father: "[...] it was this beautiful sleigh as soon as the snow appeared. No one in the village did it for their children. And my dad took us in this sleigh across the fields..." [S3], and thus she built up a correct and satisfying relationship as a teenager, being able to give: "I could not leave somebody in need of help," but also receive: "My Polish teacher motivated the class to play skits and fun games for me. Just for me" [S3], when she was unable to participate in the final secondary school ball due to her mother's illness. Taking care of her mother also contributed to her quicker maturity and responsibility: "So you just had to do it" [S3].

\section{EDUCATIONAL THREAD}

Turning to the question of education, it can be noted how family problems were a major hindrance to acquire education: "When I ran away, I spent nights at my friends' places, I went to school, or played truant. I learned to smoke and went to school less and less. I sometimes slept in the forest" [S1], and [S3]: "Unfortunately, my school record was not the best because my mother got sick when I was in 
secondary school"; as well as a long distance to get to school: "I lived in a boarding house run by nuns. It was a hard time, the bus drove me to the town and then I had to go four kilometers" [S3], another: "I had to get up very early to catch the bus, then a tram ride. Sometimes I walked to school” [S6], or warfare: “In Kraków, I started attending underground classes run in private apartments by Kraków intelligentsia. [...]. When the Russians entered the city, learning was interrupted” [S5].

Here I also notice the attitude towards the education of the child, whose effort was expected and not subject to discussion: "I was a good student, but then I did not know it, nobody said [...] that I was capable, it was not a topic. But the neighbors talked about different things, so I heard it" [S3]. The senior was finally able to reconcile her passions with a career that was not perhaps her ideal: "I finished an economics school, but I had been dreaming all my childhood to become a teacher. But when I got to that school, I could not go back. I do not regret this, because in some way I compensated my dream by teaching others what they could not understand, I helped them with mathematics lessons” [S3].

\section{PLACE OF RESIDENCE, SOCIAL RELATIONS}

An important thread in the stories of the seniors is the issue of social relations and the place of residence. "My husband found another woman after some time, we also got evicted from the apartment, because he did not pay the rent, because he had lost his job, abused alcohol" [S1]. There were more tragic developments: "I was deprived of the parental rights, the children went together for adoption. I did not want that, but I had no choice. I did not have the means, and my husband died of alcohol abuse." Finally, there was a glimmer of hope on her path: "When my husband died, I had already had a court appointed guardian and I did not want to get married. I was given an apartment by the court and I did not have a job, and because of the epilepsy I got a pension” [S1]. Thanks to this, the woman claims: "I had more quiet time, I joined a support group and then I was directed by the Labour Office to the Local Support Center in Gdańsk for the internship” [S1].

War time is also an important element in some narratives: "During the war, I was working on a German farm, so I was not deported. It was hard physical work [...]”, further: "The Russians came in the spring. They took everything, they did not even leave a piece of bread" [S1]. Another participant says, "It was hard times. [...] In Żabików, there was a very heavy labour camp. The Germans beat everybody, school children were beaten by German teachers” [S6]. It was a time of shortages: "There was a huge hunger then. I remember how hungry I was when I went to bed" [S6], and a disturbed sense of security: "The atmosphere of anxiety and fear accompanied us daily. The Germans came to the yard and fired at the 
hens. They also entered our house, and occupied the grandmother's room where Mummy lived” [S6]; another senior: "This war atmosphere on the railway siding in Kraków, the moment the air raid alarm was announced, very unpleasant, only those sirens wailing unceasingly. I was a small child, it frightened me so very much. We escaped to the shelter" [S5]. Wartime experiences were deeply engrained in his memory: "I remember the outbreak of war, I was a refugee staying with my Mummy. [...] The whole household was loaded onto railway wagons, the so called "lorry"' [S5]. These difficult experiences, in connection with the family problems, might have become a force in the struggle against the post-war reality: "I got up at four in the morning and was back at half past six in the evening. My wife did not go to work because I kept up family traditions in our home” [S5].

Another senior's tragic story played out in the social sphere: "I had a second nervous breakdown after a difficult school situation - because I am the kind of person who wants to repair the world, I want to fight for justice, I can't stand people being rude. But you cannot be alone, you must have some backing, support. I was a participant in the Solidarity strikes [...] and as punishment half of my annual salary was taken away from me. When on another occasion I began to oppose mobbing at work, I ended up losing my health and staying in hospital because of depression" [S4]. The woman goes on to say, "My story was presented in a book [...]. Here, under the pseudonym Doloris, it says how the school headmaster harassed and humiliated me. I was close to ending my life. I was forced to sign a resignation [...]. The consequences were enormous, I went through a nervous breakdown, received a disability pension [...] and that was hard to make a living” [S4].

\section{DESCRIBE MY LIFE AS HAPPY}

In the presented narratives I can find the elements of resilience, whose protective factors (Rutter, 1987) include individual characteristics, family factors, and external factors. Among the significant features of the individual interviewed respondents one can distinguish: self-esteem, cheerful disposition, faith, talents, or sociability.

Readiness to help others appears in the story of one of them: "I take care of an older grandmother who is a hundred and two years old. Helping this older person gives me so much strength that I have someone to live for. [...] I'm glad I can help older people and I have peace of mind" [S1]. Another speaks of self-reliance, selfconfidence: "I was able to cope, I attended a course for waiters and I got a job [...]" [S2]. Another says, "It is also my fight: looking after health, exercising, walking” [S3], and goes on to show her great determination: "I will not limp, I told the doctor, as long as I can cope with pain. I had crutches at the beginning, but when the 
orthopedist said that there was no cure, but I could walk six kilometers a day, so I started doing it. And now I can walk” [S3]. Another narrator is conscious of her strength: "I can say my own opinion and oppose others if I see it necessary, and that is my strength in my sensitivity at the same time" [S4], and "We have energy after our great-grandmother" [S4].

In the seniors' stories there are also elements of self-knowledge and positive self-esteem: "I am a conscientious and thorough person, I can work with devotion and passion and that is also my strength" [S4], or another: "I am cheerful, happy in everyday life" [S6], and: "I do not want to do any harm ever, maybe it is appreciated, my conciliatory approach and gentleness" [S6].

In the narratives one can also find the passions of their authors: "I love theater and operettas. We often went to the theater to the Forest Opera in Sopot” [S2]; "I was very close to the Beskid Nowosądecki Mountains, I loved walking there" [S5], and the faith that is a strong protective factor: "It is a gift from God that there were so many good people along the way, doctors who supported and treated me. It was the Divine Providence, my mother watches over me” [S4].

Apart from passion, there also comes up the topic of their goals in life and plans for the future: "In 1956, I graduated from the Silesian University of Technology. I got up at 4 am and was back at half past six pm. My wife did not go out to work because I kept family traditions in our home, my mom hadn't gone to work, either, she was a maid and looked after the house. It was the man who worked for his family and provided for it” [S5].

Family factors, such as family cohesion, close relationships, warmth, good financial situation, appear in many of the utterances: "I have a wonderful family, they care about me, sometimes I do not want to say that I feel bad not to make them worry about me, but they watch. And I feel it. I'm taken care of" [S2]; "I enjoy life, I love my great-great-grandchildren, my children” [S2]. Another senior claims: "It was a husband of convenience. Wise and good, honest, from a good family. We used to spend time together, travel. I had a son and then I was still in love with him. It was a good relationship” [S3]. Another confesses: “If not for my son, I wouldn’t have made it" [S4]. The importance of family atmosphere is emphasized by the senior: "[...] the fate of my family, my relatives, everything was going in a conflictless manner, in a climate of sympathy" [S5]. About his wife he says: "An ideal wife. My first love” [S5]. He is optimistic: "I define my life as happy” [S5]. There is another narrator on the family relationships topic: "My family and love in our family gives me strength" [S6]. Also, a woman who had experienced a difficult relationship with her husband can see his good side: "My husband was capable of painting on glass and porcelain, running a private workshop. He was able to find 
common ground with people in positions [...]. He created rationalization projects for the Refinery that had brought profit to him and to his company” [S4].

Housing and living conditions are also of great importance and appear in another narrative: “[...] we were given a two-room apartment by the shipyard” [S6]. Also the senior [S5] brings up the apartment he had got from his grandparents. The senior [S6] says: "I primarily took care of our home, of our children's education. There was no need for me to go out to work, besides, my husband would not let me have a job. It was a good time for the family" [S6].

The factor of emotional relationships is also a significant protective element: "My mother-in-law liked me. I do not mean any harm to anyone, ever. My nonconflict approach and gentleness are appreciated, I suppose. My family and love in our family gives me strength" [S6]. Significant external factors present in the stories of seniors are the proximity of friends and neighbors, as one of the seniors refers to her husband: "He was very popular, he had a lot of friends" [S2]. Another emphasizes family bonds and social contacts: "My older brother lived there at that time. We went together to have fun, and on Sunday we used to go to the Polonia Restaurant. The cashier at my workplace [...] gave me many valuable practical pieces of advice" [S3]. The importance of social relations is also evident in the story of a senior, saying, "A neighbor [...] gave me injections of magnesium that helped a lot" [S4]. She refers simultaneously to a number of her professional roles: "I had six functions at school: I was a secretary, the administrative manager, the staff person, the accountant, the cashier, all these in one and I was able to manage” [S4].

\section{PEDAGOGiCAL CHALLENGES}

The narratives that have been presented are a source of knowledge about the life of other people, especially their particularly difficult moments and borderline situations. However, their authors never give up, feel discouraged, or let their often very dramatic experiences deprive them of their desire to live, nor do they build a negative image of the world. These amazing stories with the real people behind them command my respect, but also urge me to put the question: what is it that gives them this strength to live? The above stories prove how important the protective factors can be, both these of indigenous individual nature and also these external, of social kind. According to the psychodynamic approach, the response to stress is determined by the disturbances in relationships and the ways of solving internal and interpersonal conflicts acquired in childhood. 
In turn, according to humanistic psychology, the ability to respond in difficult situations in a constructive manner is directly related to the degree the childhood needs were satisfied, especially the needs of safety (Oleś, 2011). K.R. Parkes speaks of the use of adaptive coping strategies and adaptive flexibility (Parkes, 1986), and S. Hobfoll, of the ability to increase resources and rational use of them (Hobfoll, 2006). In conclusion, Piotr Oleś defines this property in the language of psychology ego (resilience). Moreover, he believes that factors related to the development of difficult conditions in children are equally important for adults. He risks the thesis that these factors serve health and adaptive coping (Oleś, 2011). Lidia Cierpiałkowska names such factors as social competence, ability to solve problems, autonomy, awareness of purposefulness and sensibility of actions, focus on personal goals and ambition (ego science), interests and imagination, positive emotions and a sense of coherence (Cierpiałkowska, 2007).

As an educator, I can see here a vast field for development in the direction of educational processes in attaining resilience. First and foremost, the role of education promoting educational awareness, building a wise parent-child relationship and supporting the family when in crisis. It is also important to link the home environment to that of school. The experience of personalization and critical pedagogy interpreted as a disagreement with the reality should certainly be helpful here (Kwieciński \& Śliwerski, 2003). I also point out to such an understanding of pedagogy which, on the one hand, introduces and adapts the person to society and culture, and on the other, empowers the person with an emancipatory function allowing for the independent construction of identity. The humanist psychology of Abraham Maslow certainly seems to inspire the individual's self-realization (Maslow, 1990), as well as Victor E. Frankl's proposal of upbringing for responsibility (Frankl, 1978), Alfred Adler's individual psychology of social bonding (Adler, 1986), and the psychology of radical humanism of Erich Fromm, focused on the developmental potential of man and productive work (Fromm, 1999). These approaches strongly emphasize personality development and human identity processes.

I believe that the constant pursuit of pedagogical thought can support a critical approach to education and social relationships, contribute to building of human capacity, and its full use in moments of failing psychosocial stability.

\section{References:}

Adler, A. (1986). Sens życia. Warszawa: PWN.

Borucka, A., Ostaszewski, K. (2008), Koncepcja resilience. Kluczowe pojęcia i wybrane zagadnienia, Medycyna Wieku Rozwojowego, XII, 2, część I. pp. 587-597. 
Borucka, A., \& Pisarska, A. (2012). Koncepcja resilience - czyli jak można pomóc dzieciom i młodzieży z grup podwyższonego ryzyka. In: Nowe wyzwania w wychowaniu i profilaktyce. Materiały konferencyjne (pp. 82-96). Warszawa: Ośrodek Rozwoju Edukacji.

Charmaz, K. (2009). Teoria ugruntowana. Praktyczny przewodnik po analizie jakościowej. Warszawa: PWN.

Cierpiałkowska, L. (2007). Dzieci alkoholików w perspektywie rozwojowego modelu podatności i odporności na zaburzenia psychiczne, Czasopismo Psychologiczne, 13(1), pp. 7-18.

Demetrio, D. (2000). Autobiografia. Terapeutyczny wymiar pisania o sobie. Kraków: Oficyna Wydawnicza Impuls.

Dominicè, P. (2006). Uczyć się z życia. Biografia edukacyjna w edukacji dorosłych. Łódź: Wydawnictwo WSHE.

Erikson, E.H. (1972). Adolescence et crise. France: Flammarion.

Erikson, E.H. (1997). Dzieciństwo i społeczeństwo. Poznań: Dom Wydawniczy Rebis.

Erikson, E.H. (2002). Dopełniony cykl życia. Poznań: Dom Wydawniczy Rebis.

Frankl, V.E. (1978). Psychoterapia dla każdego. Warszawa: Instytut Wydawniczy PAX.

Fromm, E. (1999). Niech stanie się człowiek. Warszawa-Wrocław: PWN.

Giddens, G. (2002). Nowoczesność i tożsamość. Warszawa: PWN.

Hobfoll, S.E. (2006). Stres, kultura i społeczeństwo. Gdańsk: Gdańskie Wydawnictwo Psychologiczne.

Jagielska, G. (2014). Anioły jedzq trzy razy dziennie. 147 dni w psychiatryku. Kraków: Wydawnictwo Znak.

Kwieciński, Z., \& Śliwerski, B. (Eds.). (2003). Pedagogika. Warszawa: PWN.

Maslow, A.H. (1990). Motywacja i osobowość. Warszawa: Instytut Wydawniczy PAX.

Mendel, M. (2007). Społeczeństwo i rytuał. Heterotopia bezdomności. Toruń: Wydawnictwo Adam Marszałek.

Oleś, P. (2011). Psychologia człowieka dorosłego. Warszawa: PWN.

Olsson, C.A., Bond, L., Burns, J.M., Vella-Brodrick, D.S., \& Sawyer, S.M. (2003). Adolescent Resilience: A Concept Analysis, Journal of Adolescence, 26(1), pp. 1-11.

Ogińska-Bulik, N., \& Jurczyński, Z. (2011). Prężność u dzieci i młodzieży: charakterystyka i pomiar - Polska skala SPP 18, Polskie Forum Psychologiczne, 16(1), 7-28.

Parkes, K.R. (1986). Coping in Stressful Episodes: The Role of Individual Differences, Environmental Factors, and Situational Characteristics, Journal of Personality and Social Psychology, 51(6), pp. 1277-1292.

Rutter, M. (1987). Psychosocial Resilience and Protective Mechanisms, American Journal of Orthopsychiatry, 57(3), pp. 316-331.

Skibińska, E.M. (2006). Mikroświaty kobiet. Relacje autobiograficzne. Warszawa: Wydawnictwo ITE PIB.

Straś-Romanowska, M. (2005). Zmiana pozycji narracyjnej podmiotu jako przejaw jego rozwoju. Analiza biograficzna wybranych postaci literackich. In: E. Chmielnicka-Kuter, \& M. Puchalska-Wasyl (Eds.), Polifonia osobowości. Aktualne problemy psychologii narracji (pp. 89-108). Lublin: Wydawnictwo KUL. 